\title{
Characterization of a Differentially Expressed Phenylalanine Ammonia-Lyase Gene From Banana Induced During Mycosphaerella fijiensis Infection
}

\author{
Javier C. Alvarez ${ }^{1,2}$, Hector Alejandro Rodriguez ${ }^{1}$, Esperanza Rodriguez-Arango ${ }^{1}$, Zulma I. Monsalve ${ }^{2}$, Juan G. \\ Morales O. ${ }^{3} \&$ Rafael E. Arango I. ${ }^{1}$ \\ ${ }^{1}$ Plant Biotechnology Unit UNALMED-CIB, Corporación para Investigaciones Biológicas, Medellín, Colombia \\ ${ }^{2}$ Laboratory of Plant Molecular Biology, Instituto de Biología, Universidad de Antioquia, Medelliín, Colombia \\ 3 Departamentode Ciencias Agronomicas, Facultad de Ciencias Agropecuarias, Universidad Nacional de \\ Colombia sede Medellín, Colombia
}

Correspondence: Javier C. Alvarez, Plant Biotechnology Unit UNALMED-CIB, Corporación para Investigaciones Biológicas, Medellín, Colombia. E-mail: jcalvarez@lge.ibi.unicamp.br

Received: March 22, 2013 Accepted: April 26, 2013 Online Published: May 6, 2013

doi:10.5539/jps.v2n2p35 URL: http://dx.doi.org/10.5539/jps.v2n2p35

\begin{abstract}
Black leaf streak, caused by the fungus Mycosphaerella fijiensis, is the most important disease affecting the commercial production of banana and plantain in the world. Phenylalanine-ammonia-lyase (PAL) is an enzyme found in a large group of plants, which catalyzes the first reaction in the metabolic pathway of phenylpropanoid compounds. Phenylphenalenons, a type of phenylpropanoid metabolites, have been found in banana and have been suggested to be involved in resistance against pathogens. Thus, PAL might be an important enzyme in the plant-pathogen interaction. In this work, PAL cDNAs were isolated, and sequenced completely or partially, from different banana cultivars such as 'Calcutta 4' (Musaacuminata ssp. burmannicoides), 'Grain Nain' (AAA, Cavendish subgroup), 'Yangambi Km5' (AAA, Ibota subgroup) and 'Williams' (AAA, Cavendish subgroup). The obtained sequences were compared, and their secondary and three-dimensional structures of their deduced protein sequences were modeled. Several structural differences between cultivars were found. Additionally, expression analysis showed marked differences in the expression of PAL depending on the cultivar. In particular, PAL from black leaf streak- resistant 'Calcutta 4' showed highest expression in the early hours of infection in contrast to the susceptible 'Williams' cultivar.
\end{abstract}

Keywords: differential expression, Musa acuminata, Phenylalanine-ammonia-lyase (PAL), Mycosphaerella fijiensis

\section{Introduction}

Banana and plantain are important crops for staple food and fresh fruit export in the international markets. These crops are damaged by several diseases that cause significant losses for farmers (Robinson \& Saúco, 2010). The most important and destructive fungal disease is Black leaf streak, caused by Mycosphaerella fijiensis. Black leaf streak is controlled mainly by several fungicide sprays per year at a high cost for producers (Churchill, 2011).

M. fijiensis infection begins by deposition of spores on the leaf of the banana plant followed by germination within 2-3 hours on the leaf surface provided that a water film is present on the leaf and humidity conditions are appropriate. The germ tube then grows epiphytically for 2-3 days before penetrating the leaf via stomata in a hydrotropic response through the formation of appressoria or stomatopodia. Once inside the leaf, hyphae grow through the mesophyll layers and into the palisade tissue (Meredith, 1970; Stover, 1980). Cytological studies of the interactions between M. fijiensis, the susceptible genotype Grande Naine, have shown that there is a long period of biotrophy before any necrosis is observed. During this period, little evidence of disease can be seen externally.

Natural disease resistance is present in several wild-type bananas such as Calcutta 4 and few hybrids (Jeger et al., 1995). In some of these resistant genotypes, there is an apparent accumulation of phenolic compounds and presence of specialized polyphenol-storing cells in the parenchyma (Hoss, 2000; Torres et al., 2012). Once this compound is released into intercellular spaces, it comes in contact with the fungal hyphae and apparently limits 
their spread into the parenchyma (Beveraggi et al., 1993). Additionally, a type of secondary metabolites known as phenylphenalenons has been found in some Musa species (Quiñones et al., 2000). In vitro, these compounds show activity against $M$. fijiensis (Otálvaro, 2002). These observations argue in favor of the involvement of secondary metabolites in banana and plantain resistance against Black leaf streak disease.

Recent studies have shown that there is a rapid induction of phenylalanine ammonia-lyase, peroxidase and $\beta$-1,3-glucanase activity, in the resistant cultivar Calcutta 4 in the first at 72 hours after infection, in contrast to later induction of these enzymes in the susceptible cultivar Williams. Phenylalanine ammonia-lyase (PAL, EC 4.3.1.5) is a key enzyme involved in phenylpropanoid metabolism and catalyses the first step of this pathway by the conversion of L-phenylalanine to cinnamic acid, leading to a diverse group of plant secondary metabolites including lignins, coumarins, flavonoids and phytoalexins. Many studies suggest that PAL plays an essential role in modulating the resistance of plant tissues to abiotic stresses (Wang et al., 2007) and also in the general defense reaction against infection by pathogens in many higher plants (Dixon \& Paiva 1995; Mauch-Mani \& Slusarenko, 1996; Mur et al., 1996). Fluctuations in PAL levels are a key element in the regulation of phenylpropanoid synthesis (Cramer et al., 1989) and PAL genes are known to exhibit different spatial and temporal patterns of expression in response to environmental and fungal stimuli (Shufflebottom et al., 1993; Logemann et al., 1995; Kervinen et al., 1998; Fukasawa-Akada et al., 1996). In Musa a few partial PAL cDNA sequences including two partial isoforms named MaPAL1 and MaPAL2 from banana have been reported. MaPAL1 and MaPAL2 are known to play a role in postharvest chilling tolerance of banana fruit (Wang et al., 2007).

Due to the long symptomless period of black Sygatoka infection, it is important to have assays that can determine the onset of defense responses in an easy and reliable manner.

In view of the above in the present study, we used a partial PAL cDNA sequence from Musa acuminata for isolating and sequencing the full-length PAL cDNAs from susceptible and resistant cultivars. Gene expression analysis of banana plants after infection with pathogenic $M$. fijiensis showed a differential early expression of PAL in Black leaf streak resistant cv. Calcutta 4 compared to the susceptible $\mathrm{cv}$. Williams, suggesting that measuring the expression levels of this enzyme is a good indicator of the onset of defense responses in the Banana- Black SygatokaPathosystem.

\section{Materials and Methods}

\subsection{Plant Materials}

Black leaf streak susceptible cv. Williams (AAA) plants were obtained from the in vitro culture facilities, Plant Biotechnology Unit Universidad Católica de Oriente, Rionegro, Colombia. Resistant Calcutta 4 (AA) plants were obtained from University of Caldas, Colombia. Susceptible cv. Grain Nain (AAA) and resistant Yangambi km5 (AAA) plants were obtained from the in vitro culture collection, Plant Biotechnology Unit [CorporaciónparaInvestigacionesBiológicas (CIB)], Medellin, Colombia. Plants were kept under greenhouse conditions until infection at $29^{\circ} \mathrm{C}$ and relative humidity (RH) above $95 \%$.

\subsection{Mycosphaerella Fijiensis Strains}

Mono-ascosporic strains of M. fijiensis were obtained as previously described Mira (2004) from banana leaves collected in the Urabá region (Department of Antioquia, Colombia). Once captured, each ascospore was planted in Potato Dextrose Agar culture medium (PDA, Difco, Le Pont de Claix, France) and incubated at $25 \pm 1{ }^{\circ} \mathrm{C}$ until a colony of about $1 \mathrm{~cm}$ in diameter was obtained.

\subsection{Inoculation Preparation}

For conidia production, a suspension of mycelia was prepared from the initial mono-ascosporic colony by scrapping it with a sterile spatula and adding $10 \mathrm{ml}$ of sterile distilled water. The suspension was then filtered and concentration adjusted to $1 \times 10^{4}$ fragments per milliliter with distilled water. $1 \mathrm{ml}$ of suspension was added to petri dishes containing V8 juice Agar (Campbell Soup Company, Camden, NJ, USA) enriched with $0.2 \mathrm{~g} / \mathrm{L} \mathrm{CaCO}_{3}$. The petri dishes were incubated for 15 days in darkness, at a temperature of $26 \pm 1{ }^{\circ} \mathrm{C}$ followed by 15 more days under continuous white light at an intensity of 1500 lux. During the light incubation period, temperature was kept at $26 \pm$ $1{ }^{\circ} \mathrm{C}$.

\subsection{Inoculation with Mycosphaerella fijiensis}

Colonies in each petri dish were gently scrapped with a scalpel blade and then $5 \mathrm{ml}$ of water was added. The suspension was filtered through ethamine cloth, and the concentration of infective propagules (conidia + mycelial fragments) was determined using a Neubauer chamber and then adjusted to $10^{6}$ propagules $/ \mathrm{ml}$ in water with $2 \%$ gelatin. Inoculations were performed in 48 plants of 30 days-old and between 20 to $30 \mathrm{~cm}$ in height by spraying the 
first 3 leaves of each plant at a distance of approximately $20 \mathrm{~cm}$ with an airbrush Picasso K-3 adjusted to 50 psi. Controls of both cultivars were inoculated with a solution of $2 \%$ gelatin without infective propagules. After inoculation the plants were kept in an infection chamber with a constant temperature of $29^{\circ} \mathrm{C}$, a relative humidity

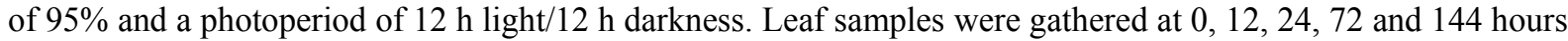
after inoculation for RNA extraction. Three leaf samples were collected per time point and plants were kept as control of infection showing necrosis development in susceptible cultivar and hypersensitive reaction in resistant cultivar (data not shown). Inoculation experiments were repeated three times at 12 months.

\subsection{RNA Isolation and cDNA Synthesis}

Total RNA was extracted from banana leaves using the Small Scale RNA Isolation kit (Invitrogen Corporation, CA, USA) according to the manufacturer's instructions. RNA concentration was measured at $260 \mathrm{~nm}$, using a NanoDrop ND-1000 UV-Vis Spectrophotometer (NanoDrop Technologies, USA). Two $\mu \mathrm{g}$ of RNA were treated with DNAse I (Fermentas Life Sciences, Hanover, USA) and purified with MinElute Cleanup columns (Qiagen, USA). First strand cDNA was synthesized by Oligo (dT) $)_{20}$ priming using SuperScript III (Invitrogen) according to the manufacturer's instructions. The RNAs were assayed for genomic DNA contamination by PCR using the specific primer set Banana B-ActinFw 5'-CAAGGAAAAGCTTGCCTACG-3' and Banana B-ActinRv 5'-CCTCCATGCCAATCAGAGAT-3'. PCR products were separated by electrophoresis in $1 \%$ agarose gels containing ethidium bromide.

\subsection{MaPAL Gene Expression Analysis Using Real-Time PCR}

cDNA from $500 \mathrm{ng}$ of the initial total RNA was used to perform real-time PCR quantification with the Light Cycler ${ }^{\circledR}$ Realtime PCR machine (Hoffman-La Roche, Nutley, NJ, USA). Fluorescent labeling was done using SYBR Green with the FastStart DNA MasterPLUS SYBR Green Kit (Roche Diagnostics, Laval, QC, Canada) following the manufacturer's instructions. PCR conditions were: $95^{\circ} \mathrm{C}$ for $30 \mathrm{~s}, 58^{\circ} \mathrm{C}$ for $20 \mathrm{~s}$, and $72{ }^{\circ} \mathrm{C}$ for $30 \mathrm{~s}$. The reaction was then incubated for $3 \mathrm{~s}$ at $2{ }^{\circ} \mathrm{C}$ lower than the melting temperature of the DNA fragment. Non-specific signals were avoided by reading of the fluorescence signal at the end of the heating, and a melting curve was performed to assess non-specific signals. The annealing temperature was selected based on the lack of appearance of non-specific bands and melting curve results. Oligonucleotide primer pairs that allow the amplification of approximately $200 \mathrm{bp}$ were designed using Primer3 software. (Rozen \& Skaletsky, 2000) and their specificity was verified by doing an aligment with sequences reported in GenBank and Banana genome database, accession EU856392 and GSMUA_Achr11T22840_001 from PAL and accessions AF246288 and GSMUA Achr1T20200 001 from Actin. Two pairs of primers were used one PAL specific primerspair: MaPALFw 5'-AAGATCACTGCCTTCGCGGA-3' and MaPALRv 5'-TCATGCCTGCTGTTGCTAGT-3' and ß-Actinspecific primers pair Ma_ß-Actinfw5'-CAAGGAAAAGCTTGCCTACG-3 and Ma_ß-Actin Rv 5'-CCTCCATGCCAATCAGAGAT-3'. The specificity of the PCR products was checked by sequencingand then blasting against the whole gene. Thebanana $\beta$-actin gene was amplified as an internal reference housekeeping gene. Each sample was assayed in triplicate and two biological samples were made. PCR efficiencies were checked to be up than 1.9. The expression ratio was calculated using the $\Delta \mathbf{\Delta C}$ t method assuming an efficiency of 2 (Pfaffl, 2001). Differences in expression between control and treated samples were calculated in-group means for statistical significance by a Pair Wise Fixed Reallocation Randomisation Test using Relative Expression Software Tool (REST), version 2009.

\subsection{Molecular Cloning of MaPAL Full-Length cDNA}

Molecular cloning of complete MaPAL cDNAs from four banana cultivars was carried out by rapid amplification of cDNA ends (RACE) using a GeneRacerTM Kit (Invitrogen Corporation, CA, USA). For 3' RACE and 5' RACE of the MaPAL gene $1 \mu \mathrm{g}$ of total RNA was reverse transcribed with GeneRacer ${ }^{\mathrm{TM}}$ OligodT primer using SuperScript TM III Reverse Transcriptase (Invitrogen Corporation, CA, USA). GeneRacer ${ }^{\mathrm{TM}}$ 3' Primer, GeneRacerTM 3' Nested Primer, gene-specific primers GSP-F (5'-TCCCCTCGAACCTTTCCGGTGGAAGA-3', as 3' RACE first amplification primer) GSP-F nested (5'-CCTCCAGGAAGACAGCCGAGGCAGTAG-3', as 3' RACE nest amplification primer) were used. For 5' RACE;GeneRacerTM 5' Primer, GeneRacer ${ }^{\mathrm{TM}} 5$ ' Nested Primer, gene-specific primers GSP-R (5'-TCCGGGAGACGTCAATGAGGGGGTTGT-3', as 5' RACE first amplification primer) GSP-R nested (5'-TCGATTTGGCCCGGGTGGTGCTTCA-3', as 5' RACE nest amplification primer) were used. The PCR was conducted in accordance to the protocol provided by the manufacturer (Invitrogen Corporation, CA, USA). Amplified PCR products were cloned into TOPO ${ }^{\circledR}$ TA Cloning (Invitrogen Corporation, CA, USA) and pGEM-T ${ }^{\circledR}$ (Promega, USA) vectors and then sequenced. Assembling the products of $3^{\prime}$ and 5'-RACE full length MaPAL sequence from banana cv. Calcutta 4 and cv. Grand Nain, and partial sequence from $\mathrm{cv}$. Yangambí $\mathrm{km} 5$ and $\mathrm{cv}$. Williams were assembled by aligning and then confirmed by PCR amplification using 
PlatinumTM Taq polymerase (Invitrogen Corporation, CA, USA) with primers PAL full length Fw (5'-AAACACCTTGGGGAGATCAA-3') and PAL full length Rv 5'-ATAAGCACACACAACTGGAAT-3' in Calcutta 4 and Grand Nain. The PCR procedure was conducted under the following conditions: 4 min at $94{ }^{\circ} \mathrm{C}, 30$ cycles $\left(1 \mathrm{~min}\right.$ at $94{ }^{\circ} \mathrm{C}, 1 \mathrm{~min}$ at $53{ }^{\circ} \mathrm{C}, 3 \mathrm{~min}$ at $\left.68^{\circ} \mathrm{C}\right)$ and $10 \mathrm{~min}$ at $68^{\circ} \mathrm{C}$.

\subsection{Sequence Analyses of MaPAL}

Sequencing service was conducted by the company Macrogen using the 3730XL DNA sequencer. Sequence descontamination and Genbank BLASTs were carried out on VectorScreen-NCBI. Edition and multiple alignments (using Clustal W) were carried out using the Bioedit software (Hall, 1999). Sequence ensembles, ORF translation and molecular mass calculation of the predicted protein were carried out on Lasergene (Geneious Pro version 5.1, 2011). The software jModelTest was used to determine the nucleotide model of substitution (Nei \& Kummar, 2000; Posada, 2008). Phylogenetic analysis of MaPAL and other plant PAL sequences retrieved from GenBank were realized using Mega 5 (Kummar et al., 2008) for cladogram construction based on maximum likelihood and 500 bootstrapping. Secondary structural analysis of the predicted MaPAL protein was carried out on the website of SOPMA Server (Geourjon \& Deléage, 1995; Combet et al., 2000). Homology based structural modeling was performed by Swiss-Model (Arnold et al., 2006) (http://swissmodel.expasy.org) using $1 \mathrm{~W} 27$ from Protein Data Bank as template, and PyMOLversión 0.97 (Molecular graphics systems, free trial, 2004) was used to display 3-D structures.

\section{Results}

\subsection{Cloning of MaPAL Full-Length cDNA}

3'-RACE and 5'-RACE were used to isolate the full-length cDNA encoding PAL from resistant banana cv. Calcutta 4 and Yanganmbi Km5, and susceptible cv. Williams and Grand Nain. Specific primers were designed based on a banana PAL sequence reported in GenBank (accession AJ555536). After two rounds of amplification, fragments between 900 and 1000 bp from the 3' gene region were obtained for every cultivar. Polymorphisms were identified upstream of the polyadenylation sites (Figure 1). Similarly, 5' PAL region of each cultivar was assembled from several transcripts amplified in the two rounds of 5'RACE. Transcriptional and polyadenylation signals were identified at the end 3' of the transcript (Figure 1).

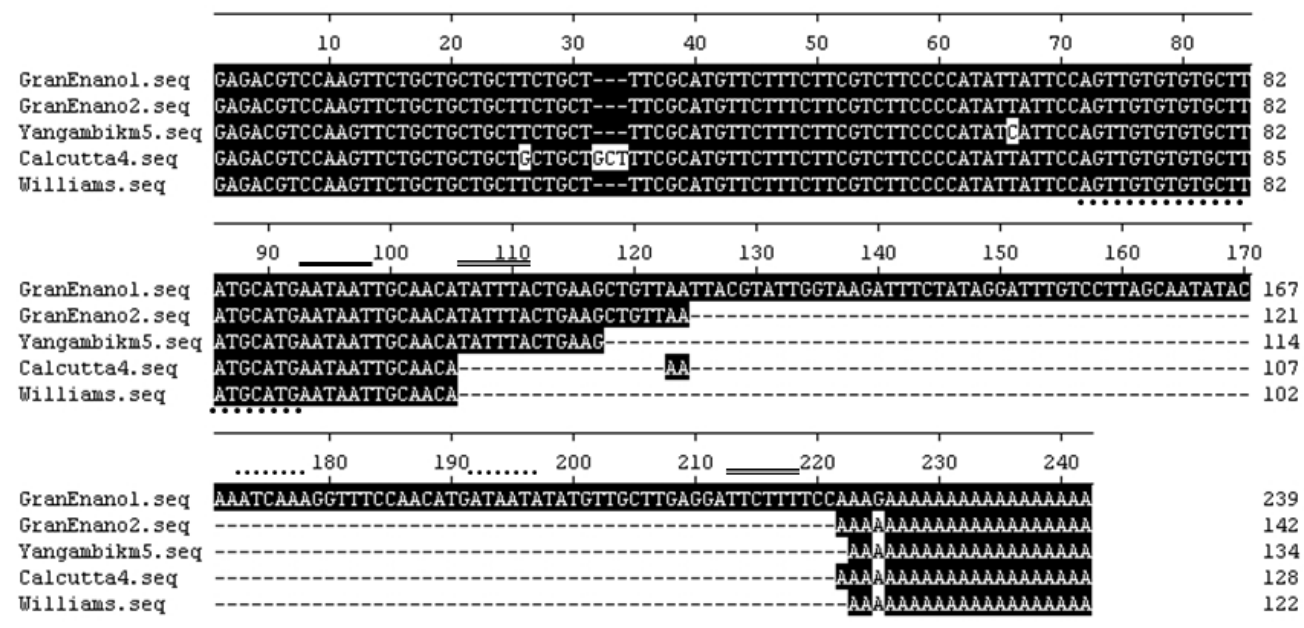

Figure 1. 3' UTR MaPALalignment from four banana cultivars

Dark solid bar: polyadenylation signal; dotted bar: polyadenylation alternative sites (PAS); double bar: cut elements (CE); dark spots bar below sequence: putative binding site of homologous miR1030j.

Full-length MaPALcDNA sequence from the Black sigatoka resistant banana cv. Calcutta 4 exhibited a length of $2821 \mathrm{bp}$ with an ORF of $2136 \mathrm{bp}$ that codes for a putative protein of 712 aa, a 3'UTR of 186 bpand a 5'UTR of 472 bp. From the Black sigatoka banana cv. Grand Nain a full-length MaPAL cDNA sequence of 2932 bp with an ORF of $2139 \mathrm{bp}$ encoding a putative protein of 713aa, a 3' UTR of $300 \mathrm{bp}$ and a 5' UTR of $470 \mathrm{bp}$ was obtained. From resistant cv. Yangambí Km5, 1753 bp corresponding to a putative protein region of 584 aa coding 
for the MaPAL exon II and 196 bp corresponding to the 3'UTR were identified. From susceptible cv. Williams 583 aa of the MaPAL protein and 196 bp of corresponding 3'UTR were analyzed (Figure 1). The MaPAL sequences were submitted to the GenBank databases under accession numbers EU856392, EU856393, EU862232 and EU862233.

\subsection{Analysis of Deduced MaPAL Proteins}

The deduced amino acid sequences obtained from the cDNAs sequenced were used for bioinformatics analysis. A high degree of identity of the amino acids sequences (92.6\%) were found between PAL proteins of Calcutta 4, Grand Nain, Williams and MaPAL2 protein reported by Wang et al. (2007). Whereas the Yangambi km5 PAL protein had more identity (87.4\%) to the MaPAL1 isoform reported previously by Wang et al. (2007). Most changes observed were located in the amino acids of the N-terminus and near the junction area of exon I and exon II (Figure 2). The proteins have a calculated weight net of approximately $77.49 \mathrm{kDa}$, consistent with a molecular weight reported of 72 to $83 \mathrm{kDa}$ for PAL proteins determined by physicochemical methods (Schomburg \& Salzmann, 1990).

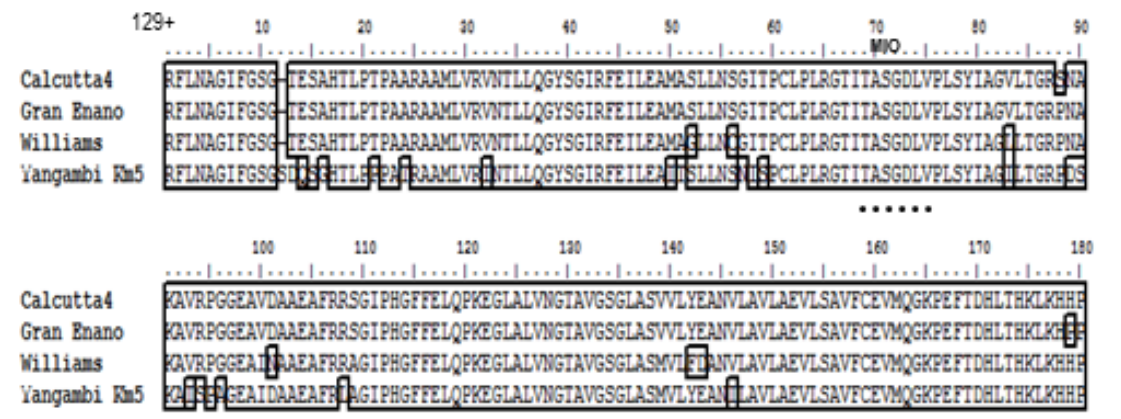

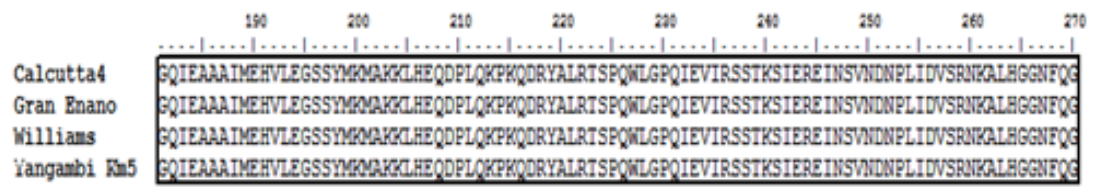

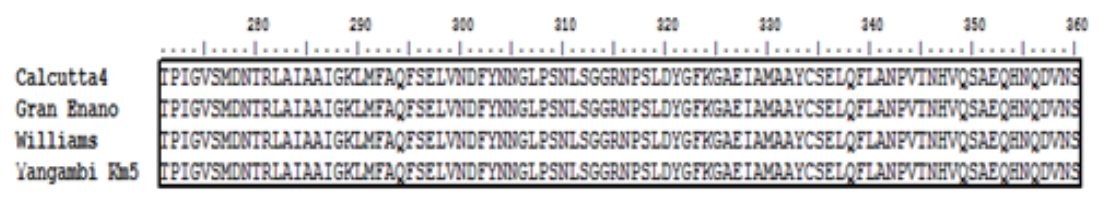
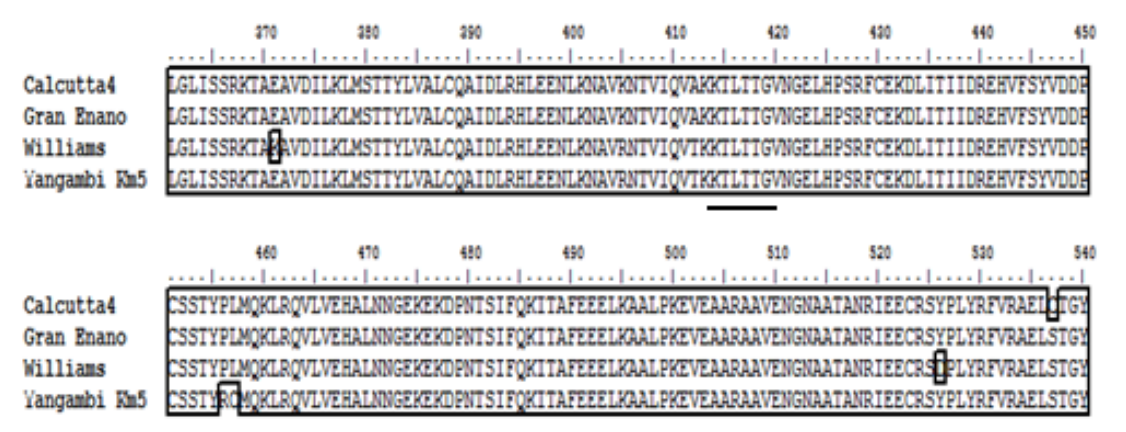

\begin{tabular}{|c|c|}
\hline & $\begin{array}{cccc}550 & 560 & 590 & 580 \\
\ldots|\ldots \ldots| & \ldots & \ldots & \end{array}$ \\
\hline Calcutta4 & FTGEKVSPGEDFDKIFAAIKGMWIDPLLCCKENDGAPLPIQ \\
\hline Gran Bnano & 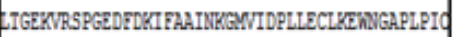 \\
\hline Willians & 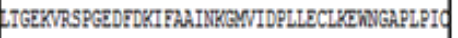 \\
\hline Vangambi $\mathrm{Kan} 5$ & LTGEKVRPGEDFDKIFAAINKGWIDPLIECCKEWNGAPLPID \\
\hline
\end{tabular}

Figure 2. Multiple alignment of deduced PAL proteins from Exon II

Cultivars: Calcutta 4, Grain Nain, Williams and Yangambí Km5. Dotted bar indicate the active site conserved sequence MIO. Solid bar indicate the conserved phosphorylation site VAKRTLTT. 


\subsection{Phylogenetic Analysis}

To investigate the evolutionary relationships of MaPAL genes, a phylogenetic analysis using nucleotide sequences of PAL proteins from various taxonomic groups of flowering plants was performed using the Jukes-Cantor model from maximum likelihood method (Saitou \& Nei, 1987). The PAL sequence of the gymnosperm Pinus taeda, was used as an out-group because it has already been described as belonging to an ancient group of flowering plants (Chaw et al., 1997; Lu et al., 2006(a)). Due to the low amino acid conservation at the N-terminal region of PAL proteins, only the exon II sequences $(\sim 1764 \mathrm{nt})$ were used for analysis. This argument also was used by De Paolis et al. (2007). This exon contains the conserved catalytic site and the phosphorylation site. Taxonomic families were consistently grouped within the phylogenetic tree and the MusaMaPAL proteins were located inside a monophyletic group of monocots (Figure 3).

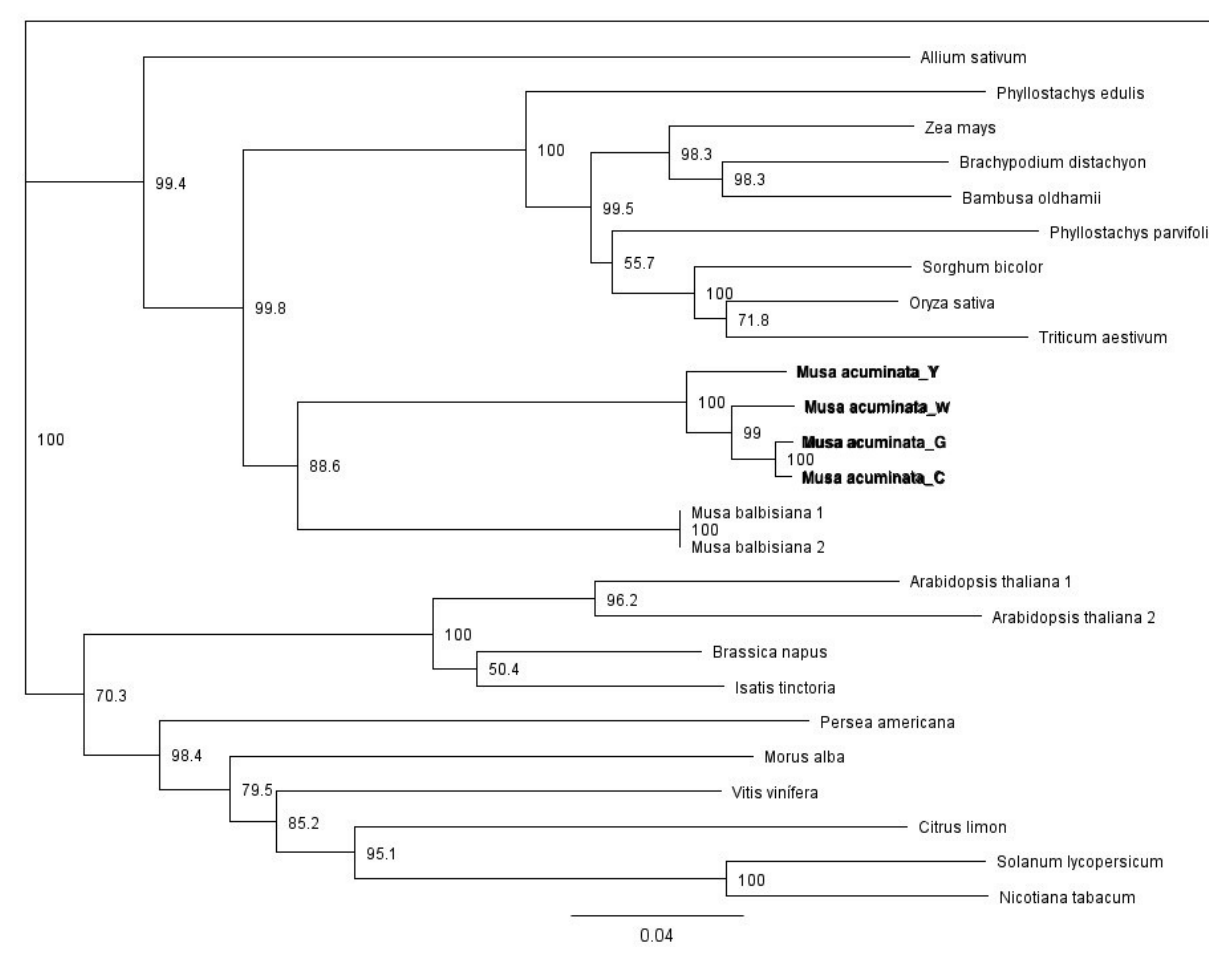

Figure 3. Maximum likelihood phylogenetic tree of the deduced nucleotide sequences of MaPAL and other plant PAL proteins using PAL sequence from Pinus taeda (GenBank Accession PTU39792) as outgroup

Arabidopsis thaliana 1PAL1 (NM129260); Arabidopsi sthaliana 2 PAL2 (NM115186); Brassica napus (DQ341309); Isatis tinctoria (DQ468345); Persea Americana (PAU16130); Citrus limon (CLU43338); Solanum lycopersicum (M90692); Nicotiana tabacum (M84466); Vitis vinifera (JN858957); Morus alba var. multicaulis (HQ025956); Musa acuminata Calcutta 4 (C): EU856392, Gran enano (GE): EU856393, Yangambi km5 (Y): EU862232, Williams (W): EU862233); Musa balbisiana PAL1, MBP_94I16; PAL2, MBP_71C19; Allium sativum GU456381); Phyllostachys edulis FJ195650); Phyllostachys parvifolia FJ592178); Triticum aestivum (AK333035); Oryza sativa (J013026F02); Sorghum bicolor (XM_002454154); Zea mays (NM_001153961); Brachypodium distachyon (XM_003580096); Bambusa oldhamii (GÜ338002).

\subsection{Analysis of the Putative Secondary Structure of MaPAL Proteins}

PAL predicted proteins were modeled in a three-dimensional structure looking for structural polymorphisms due to changes in the amino acid sequence (Figure 4). MaPAL protein from cv. Calcutta 4 was predicted to have 391 amino acids in alpha helices (54.92\%), 226 in random coils (31.74\%), 58 extended strand (8.15\%) and 37 in beta turns (5.2\%). Modeling allowed the localization of the putative active site of the predicted protein, the phosphorylation site, and the junction area of the predicted sequences (Figure 4). An alignment of the secondary structure of MaPAL proteins showed a structural variation of putative MaPAL protein from cv. Calcutta 4 compared with the MaPAL predicted structure from cv. Yangambí Km5. In MaPAL predicted protein from cv. Yangambí km5 a beta 3 turn was observed. In contrast, a random coil was observed in cv. Calcutta 4, Williams 
and Grand Nain. This change in the predicted secondary structure was located near the active site of MaPAL and is due to the loss of Ser 141 and change of 142 (DQ G) by also polar residues in cv. Calcutta 4 141 (TE A) (Figure 4, box C). Comparison of the molecular surface showed an electrostatic potential change in the MIO domain, turning the Calcutta MaPAL protein less negatively charged (Figure 4, box A and B).

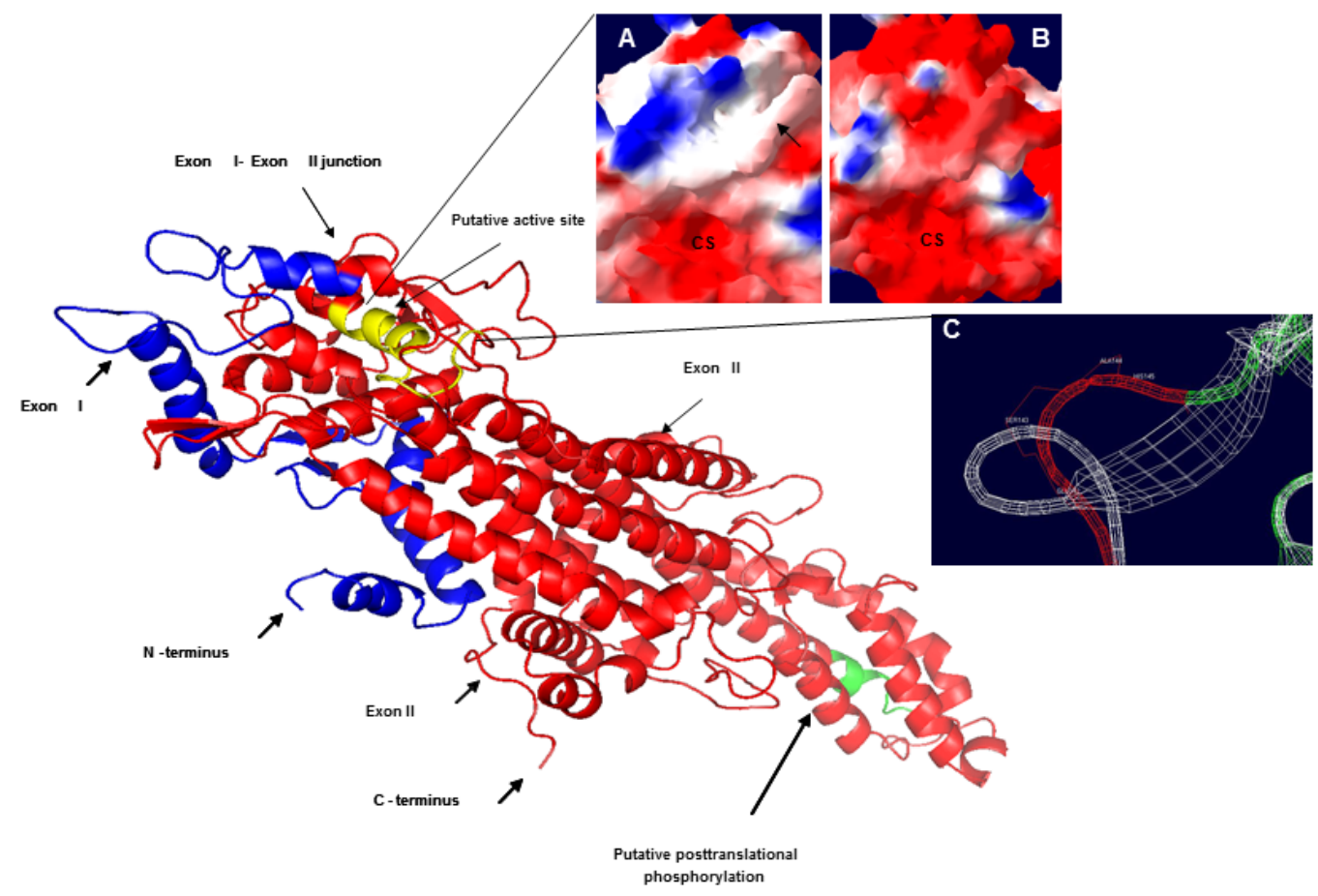

Figure 4. Three-dimensional structures of the deduced MaPAL protein cv. Calcutta 4 using 1 W27 from Protein Data Bank as template

A. Electrostatic potential of MIO domain from Calcutta 4.

B. Electrostatic potential of MIO domain from Yangambí Km5.

C. Structural alignment between Calcutta 4 protein (in red) and Yangambí Km5 protein (in white).

Arrow shows putative hydrofobicity change. Catalytic Site (CS). Modeling by sequence homology on Swiss-model server and PyMOL version 0.97 (Molecular graphics systems, free trial 2004).

\subsection{Expression of MaPAL During Interaction With M. fijiensis}

MaPAL gene in resistant cv. Calcutta 4 showed significant over-expression at 12 (10.5-fold), 24 (25.99-fold) and 144 (9.55-fold) Hours After Inoculation (HAI), in contrast, the MaPAL gene expression in the susceptible cv. Williams, only exhibited a mild up-regulation at 12 (1.77-fold) and 144 (1.6-fold) HAI. The remaining time points did not show significant differences between the two cultivars. All experiments were performed twice with similar results. The most significant MaPALover-expression in the cultivar Calcutta 4 was found at 24 HAI. At this point, the gene showed an up-regulation of 25.24-fold more that Williams (Figure 5). 


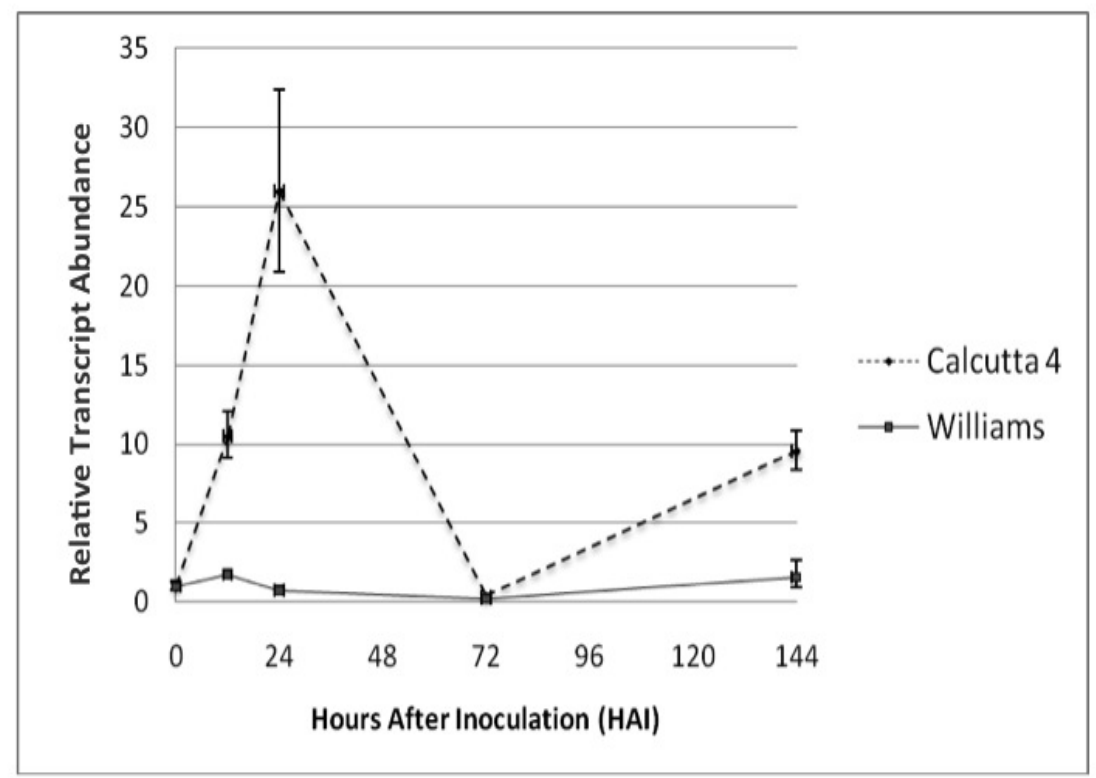

Figure 5. Relative expression level ofMaPAL in resistant and susceptive cultivars during $M$. fijiensis infection qPCR analysis was done by using SYBR green. The relative expression level was calculated comparing to housekeeping $B$-Actin gene levelusing the $2^{-\Delta \Delta \mathrm{Ct}}$ method.

\section{Discussion}

The identification and characterization of MaPAL gene are an important step to understand the role this enzyme has in the Musa defense response mechanisms against phytopathogens. In the present study, complete and partial cDNAs coding for the phenylalanine ammonia-lyase enzyme from two resistant and two susceptible cultivars of Musa acuminata were isolated and characterized. The full lengthcDNA of MaPAL was about $2.9 \mathrm{~kb}$ in size with an open reading frame of $2139 \mathrm{bp}$, which is consistent with previous report for the PAL gene in beans (Cramer et al., 1989).

\subsection{Polymorphisms on the 3'UTR From MaPAL Genes}

Sequence alignments of the 3'UTR from MaPAL sequence revealed that these transcripts have an insert (until $100 \mathrm{bp}$ ) downstream of the classic polyadenylation signal in cv. Grand Nain and in cv. Yangambi km5 (AATAA), (MacDonald \& Redondo, 2002) (Figure 1). Polymorphism in 3'UTR was also found in MaPAL from cv. Williams by Wang et al. (2007). They described two isoforms: PAL1 and PAL2, which exhibited almost the same pattern of expression when banana plants were treated with propylene and exposed to chilling temperatures. This longer sequence could provide more stability or mRNA translation efficiency due to the presence of downstream un-translated cis elements (DUEs), which can choose alternative polyadenylation sites and have a stronger effect on the final expression of this gene (Lu et al., 2006 (b)). In the 3'UTR of MaPAL from cv. Grand Nain several alternative polyadenylation sites (PAS) were present downstream of the classical AATAA polyadenylation signal. Two A-rich sequences ATCAAA (-50) and ATAATA (-32) were identified as PAS sites. Most mRNAs are considered to contain multiple PASs in their 3'-UTRs and this could play an important role in heterogeneity of mRNA. The selection of a PAS is thought to be cell-type, tissue-type, developmental stage or disease-type specific (Mignone et al., 2002; Beaudoing \& Gautheret, 2001). Moreover, selective polyadenylation may be crucial for post-transcriptional regulation of gene expression because it affects the stability of mRNAs, attenuates protein synthesis and controls sub-cellular localization (Mignone et al., 2002).

Conserved dinucleotides YA (CA or TA) were also found in the end of each sequence. These are Cleavage Sites (CS) present before the polyadenylation site (-1) (Li \& Hunt, 1995). Cv. Grand Nain and cv. Yangambi km5 cDNAs have the extra signal elements TCTTTT at -7 and TATTTA at -118 and -10 respectively. These elements have been widely identified in the transcriptome of the genetic model plant Arabidopsis. There were named Cleavage Elements (CE) because they have the potential to form secondary structures and may have an impact on the efficiency of the 3'-End Region signals (Loke et al., 2005). 


\subsection{Modeling and Structure of the MaPAL Protein}

The Exon II of PAL gene is highly conserved in most plant species. This part of the PAL sequence contains the active site of the enzyme, a phosphorytation motif and the main structural domains. In contrast the Exon I portion of the PAL gene has showed divergence in most plant species reported in the literature (Cramer et al., 1989; Lu et al., 2006). The alignment of the predicted amino acid sequences of the MaPAL exon II from the four cultivars analyzed in this work indicated that the N-terminal region which is close to the active site is the most divergent portion of the enzyme (Figure 2). This may be significant in the secondary and quaternary conformations of the corresponding protein, particularly in MaPAL from $\mathrm{cv}$. Yangambi km5 where most polymorphisms were detected.

The active site of the PAL enzyme named MIO (Calabrese et al., 2004) was conserved in the four cultivars analyzed and it was found to be located between amino acid residues 66 and 83. Two PAL serine residues, which are conserved in many species of higher plants, were found in positions 71 and 78 (Figure 2). In these serine residues resides the catalytic lyase activity of the PAL enzyme (Schuster \& Rétey, 1994). A conserved phosphorylation site (Thr-543 on VKRTLTT) was also identified in the predicted proteins from all cultivars (Figure 2). This phosphorylation site was also reported from Phaseolus vulgaris (Allwood et al., 1999), Arabidopsis thaliana (Cheng et al., 2001) and Isatisindigotica (Lu et al., 2006), suggesting that post-translational phosphorylation may be involved in modulating the MaPAL activity.

\subsection{Divergence of PAL Proteins from Banana}

Previous analyses performed with PAL sequences (Lu BB et al., 2006; De Paolis et al., 2007) and current classifications made by molecular markers (NCBI taxonomy database) were consistent to the generated phylogenetic tree. This analysis suggests that PAL in Musa acuminata diverged from a common ancestor together with the Poaceae group more than 130 Million years ago, time estimated as the origin of the monocots (Sanderson et al., 2004). Phylogenetic MaPAL protein analysis indicates that corresponding genes have diverged amongst the cultivars examined. Additionally, it appears that the PAL sequences from banana cultivars isolated in this work are close to the MaPAL2 sequence reported byWang et al. (2007). The MaPAL sequence from cv. Yangambí Km5 was the most ancient from the four predicted proteins and had the highest identity to the 1w27A PDB template from Petroselinum crispum (Ritter \& Schulz, 2004). However, the MaPAL predicted protein from cv. Calcutta 4 showed a significant change on the modeled secondary structure not present on the protein structure from $\mathrm{cv}$. Yangambi $\mathrm{km} 5$ and the previously reported protein $1 \mathrm{w} 27 \mathrm{~A}$ which may represent a significant change on hydrofobicity and may affect the physicochemical properties of this protein (Figure 5, A and B).

\subsection{PAL Gene Expression in Different Banana Cultivars}

Differences in PAL gene expression amongst the Musa cultivars analyzed were observed. MaPAL gene expression profile from cv. Calcutta 4 infected with M. fijiensis showed up-regulation peaks at 12 hours, 24 hours and 144 hours after infection (Figure 5). In contrast, in the susceptible cv. Williams a lower level of expression was observed in all time points evaluated. This result was consistent with earlier experiment performed by semi quantitative PCR in our laboratory; where high levels of MaPAL mRNA were observed in resistant Calcutta 4 at 3 and 12 hours after inoculation with M. fijiensis. In contrast MaPAL gene expression from susceptible cv. Williams did not show induction upon M. fijiensis infection.

The first hours of pathogen colonization are very important for the outcome of the interaction. The synthesis of defense related compounds including secondary metabolites such as phythoalexines, flavonoids and lignins is performed early during the interaction (Sreelakshmi \& Sharma, 2008). Moreover, a faster response in resistant varieties compared to the susceptible ones has been described previously in other pathosystems (Da Cunha et al. 2006). The principal role of PAL is to deaminate phenylalanine to trans-cinnamic acid to be quickly transformed into lignin for accumulation in the intercellular spaces, cell wall thickening and possibly blocking the growth of fungus (Hoss et al., 2000; Khan et al., 2004). Therefore, possibly the fact that PAL is over-expressed in the early hours, is an important step for resistant varieties such as Calcutta 4, to increase the production of secondary metabolites such as phenylphenalenones and lignin in the leaf tissue cells, and thereby effectively control the spread of fungus (Quiñones et al., 2000; Dubery, 2006).

In this work, we found evidence suggesting an active role for the MaPAL protein during the early banana-Mycosphaerella fijiensis interactions. Further gene functional and protein kinetics experiments are required to fully understand the precise role this enzyme plays in the banana defense responses against the plant pathogen Mycosphaerella fijiensis. Whatever the role of MaPAL in the defense response, we believe that the over-expression of this gene constitutes a good indicator of the onset of defense responses in the banana- $M$. fijiensis pathosystem. 


\section{Acknowledgements}

This work was supported by Instituto para el desarrollo de la Ciencia y la Tecnología "Francisco José de Caldas" (Colciencias), Colombia, Project grants: No. 2213-452-21253 and No. 2213-12-17825. Dirección de Investigaciones Medellín (DIME) from Universidad Nacional de Colombia sede Medellín, Project grant No. 20101006122. Comité para el Desarrollo de la Investigación (CODI) from Universidad de Antioquia, Project grant No IN549CE and Corporación para Investigaciones Biológicas (CIB).

\section{References}

Allwood, E. G., Davies, D. R., Gerrish, C., Ellis, B. E., \& Bolwell, G. P. (1999). Phosphorylation of phenylalanine ammonia-lyase: evidence for a novel protein kinase and identification of the phosphorylated residue. FEBS Letters, 457, 47-52. http://dx.doi.org/10.1016/S0014-5793(99)00998-9

Arnold, K., Bordoli, L., Kopp, J., \& Schwede, T. (2006). The SWISS-MODEL Workspace: A web based environment for protein structure homology modelling. Bioinformatics, 22, 195-201. http://dx.doi.org/10.1093/bioinformatics/bti770

Beaudoing, E., \& Gautheret, D. (2001). Identification of alternate polyadenylation sites and analysis of their tissue distribution using EST data. Genome Res., 11, 1520-1526. http://dx.doi.org/10.1101/gr.190501

Beveraggi, A., Mourichon, X., \& Salle, G. (1993). Study of host-parasite interactions in susceptible and resistant bananas inoculated with Cercospora fijiensis, pathogen of black leaf streak disease. In J. Ganry (Eds.), Breeding Banana and Plantain for resistance to disease and pests (pp. 213-220). Montpellier, France: CIRAD, INIBAP.

Calabrese, J. C., Jordan, D. B., Boodhoo, A., Sariaslani, S., \& Vannelli, T. (2004). Crystal structure of phenylalanine ammonia lyase: multiple helix dipoles implicated in catalysis. Biochemistry, 14, 11403-16. http://dx.doi.org/10.1021/bi049053+

Chaw, S. M., Zhaekikh, A., Sung, H. M., Lau, T. C., \& Li, W. H. (1997). Molecular phylogeny of extant gymnosperms and seed plant evolution: Analysis of nuclear 18S rRNA sequences. MolBiolEvol, 14, 56-68. http://dx.doi.org/10.1093/oxfordjournals.molbev.a025702

Cheng, S. H., Sheen, J., Gerrish, C., \& Bolwell, G. P. (2001). Molecular identification of phenylalanine ammonia-lyase as a substrate of a specific constitutively active Arabidopsis CDPK expressed in maize protoplasts. FEBS Lett., 503, 185-188. http://dx.doi.org/10.1016/S0014-5793(01)02732-6

Churchill, A. C. (2011). Pathogen profile Mycosphaerella fijiensis, the black leaf streak pathogen of banana: progress towards understanding pathogen biology and detection, disease development, and the challenges of control. Molecular Plant Pathology, 12, 307-328. http://dx.doi.org/10.1111/j.1364-3703.2010.00672.x

Combet, C., Blanchet, C., Geourjon, C., \& Deléage, G. (2000). NPS@: Network Protein Sequence Analysis. TIBS, 2, 147-150. http://dx.doi.org/10.1016/S0968-0004(99)01540-6

Cramer, C. L., Edwards, K., Dron, M., Liang, X., Dildine, S. L., Bolwell, G. P., ... Schuch, W. (1989). Phenylalanine ammonia-lyase gene organization and structure. Plant Molecular Biology, 12, 367-383. http://dx.doi.org/10.1007/BF00017577

Da Cunha, L., McFall, A., \& Mackey, D. (2006). Innate immunity in plants: a continuum of layered defenses. Microbes and infection, 8, 1372-1381. http://dx.doi.org/10.1016/j.micinf.2005.12.018

De Paolis, A., Pignoneb, D., Morgeseb, A., \& Sonnante, G. (2007). Characterization and differential expression analysis of artichoke phenylalanine ammonia-lyase-coding sequences. Physiologia Plantarum, 132, 33-43. http://dx.doi.org/10.1111/j.1399-3054.2007.00996.x

Dixon, R. A., \& Paiva, N. L. (1995). Stress-induced phenylpropanoid metabolism. Plant Cell, 7, 1085-1097. doi:10. 1105/tpc.7.7.1085

Dubery, I. A. (2006). Soluble and wall-bound phenolics and phenolic polymers in Musa acuminata roots exposed to elicitors from Fusariumoxysporumf. sp. cubense. Phytochemistry, 63, 679-686. http://dx.doi.org/10.1016/S0031-9422(03)00286-3

Fukasawa-Akada, T., Shain-dow, K., \& Watson, J. C. (1996). Phenylalanine ammonia-lyase gene structure, expression and evolution in Nicotiana. Plant Molecular Biology, 30, 711-722. http://dx.doi.org/10.1007/BF00019006

Geourjon, C., \& Deléage, G. (1995). SOPMA: Significant improvement in protein secondary structure prediction 
by consensus prediction from multiple alignments. Comput Appl Biosci., 11, 681-684.

Hall, T. A. (1999). BioEdit: a user-friendly biological sequence alignment editor and analysis program for Windows 95/98/NT. Nucl. Acids. Symp. Ser., 41, 95-98.

Hoss, R., Helbig, J., \& Bochow, H. (2000). Function of Host and Fungal Metabolites in Resistance Response of Banana and Plantain in the Black leaf streak Disease Pathosystem (Musa spp. -Mycosphaerella fijiensis). J Phytopathol, 148, 387-394. http://dx.doi.org/10.1046/j.1439-0434.2000.00530.x

Jeger, M. J., Eden-Green, S., Tresh, J. M., \& Johanson, A. (1995). Waller, J. M., \& Brown, A. E. Banana diseases. In Gowen, S. Chapman \& Hall (Eds.), (pp. 317-381) Bananas and Plantains. London, UK.

Kervinen, T., Peltonen, S., Teeri, T. H., \& Karjalainen, R. (1998). Differential expression of phenylalanine ammonia-lyase genes in barley induced by fungal infection or elicitors. New Phytol, 139, 293-300. http://dx.doi.org/10.1046/j.1469-8137.1998.00202.x

Khan, W., Prithiviraj, B., \& Smith, D. L. (2004). Chitosan and chitin oligomers increase phenylalanine ammonia-lyase and tyrosine ammonia-lyase activities in soybean leaves. J Plant Physiol., 160, 859-863. http://dx.doi.org/10.1078/0176-1617-00905

Kumar, S., Nei, M., Dudley, J., Tamura, K. (2008). MEGA: a biologist-centric software for evolutionary analysis of DNA and protein sequences. Brief Bioinform, 9, 299-306. http://dx.doi.org/10.1093/bib/bbn017

Li, Q. Q., \& Hunt, A. G. (1995). A near upstream element in a plant polyadenylation signal consists of more than six bases. Plant Mol Biol., 28, 927-934. http://dx.doi.org/10.1007/BF00042076

Logemann, E., Parniske, M., \& Hahlbrock, K. (1995). Modes of expression and common structural features of the complete phenylalanine ammonia-lyase gene family in parsley. PNAS, 92, 5905-5909. http://dx.doi.org/10.1073/pnas.92.13.5905

Loke, J. C., Stahlberg, E. A., Strenski, D. G., Haas, B. J., Wood, P. C., \& Li, Q. Q. (2005). Compilation of mRNA polyadenylation signals in Arabidopsis revealed a new signal element and potential secondary structures. Plant Physiology, 138, 1457-1468. http://dx.doi.org/10.1104/pp.105.060541

Lu, B. B., Du, Z., Ding, R. X., Zhang, L., Yu, X. J., Liu, C. H., \& Chen, W. S. (2006). Cloning and Characterization of a differentially expressed Phenylalanine Ammonialyase gene IiPAL.after genome duplication from tetraploid Isatis indigotica Fort. Journal of Integrative Plant Biology, 48, 1439-1449. http://dx.doi.org/10.1111/j.1744-7909.2006.00363.x

Lu, Y., Gao, C., \& Han, B. (2006). Sequence analysis of mRNA polyadenylation signals of rice genes. Chinese Science Bulletin, 55, 1069-1077. http://dx.doi.org/10.1007/s11434-006-1069-5

Nei, M., \& Kumar, S. (2000). Molecular evolution and phylogenetics. Oxford: Oxford University Press.

MacDonald, C. C., \& Redondo, J. L. (2002). Reexamining the polyadenylation signal: Were we wrong about AAUAAA? Mol Cell Endocrinol, 190, 1-8. http://dx.doi.org/10.1016/S0303-7207(02)00044-8

Mauch-Mani, B., \& Slusarenko, A. (1996). Production of salicylic acid precursors is a major function of phenylalanine ammonialyase in the resistance of Arabidopsis to Peronosporaparasitica. Plant Cell, 8, 203-212.

Meredith, D. S. (1970). Banana leaf spot disease (Sigatoka) caused by Mycosphaerella musicola Leach. (Commonwealth Mycological Institute, Kew, Surrey, England).

Mignone, F., Gissi, C., Liuni, S., \& Pesole, G. (2002). Untranslated regions of mRNAs. Genome Biol., 3, REVIEWS0004.

Mira, J. J. (2004). Caracterización mediante métodos biológicos de aislamientos de Mycosphaerella fijiensis Morelet resistentes y sensibles a fungicidas utilizados en su manejo químico en la zona de Urabá Colombia. Universidad Nacional de Colombia, Medellín. Facultad de Ciencias Agrarias. Maestría en ciencias Agrarias. p. 99.

Mur, L. A. J., Naylor, G., Warner, S. A. J., Sugars, J. M., White, R. F., \& Draper, J. (1996). Salicylic acid potentiates defence gene expression in leaf tissue exhibiting acquired resistance to pathogen attack. Plant Journal, 9, 559-571. http://dx.doi.org/10.1046/j.1365-313X.1996.09040559.x

Otálvaro, F., Echeverri, F., Quiñones, W., Torres, F., \& Schneider, B. (2002). Correlation between phenylphenalenonephytoalexins and phytopathological properties in Musa and the role of a dihydrophenylphenalenetriol. Molecules, 7, 331-340. http://dx.doi.org/10.3390/70300331 
Pfaffl, M. W. (2001). A new mathematical model for relative quantification real-time RT-PCR. Nucleic Acids Research, 29, 2002-2007. http://dx.doi.org/10.1093/nar/29.9.e45

Posada, D., \& Buckley, T. R. (2004). Model selection and model averaging in phylogenetics: advantages of Akaike information criterion and Bayesian approaches over likelihood ratio tests. Syst Biol, 53, 793-808. http://dx.doi.org/10.1080/10635150490522304

Quiñones, W., Escobar, G., Echeverry, F., Rosero, Y., Arango, V., Cardona, G., \& Gallego, A. (2000). Synthesis and antifungal activity of Musaphytoalexins and structural analogs. Molecules, 5, 974-980. http://dx.doi.org/10.3390/50700974

Ritter, H., \& Schulz, G. E. (2004). Structural basis for the entrance into the phenylpropanoid metabolism catalyzed by phenylalanine ammonia-lyase. Plant Cell, 16, 3426-3436. http://dx.doi.org/10.1105/tpc.104.025288

Robinson, J. C., \& Saúco, V. (2010). Crop production Science in Horticulture Series, Bananas and Plantains (2nd ed.). Design. La Laguna, Tenerife, Spain: CAB International.

Rozen, S., \& Skaletsky, H. J. (2000). Primer3 on the WWW for general users and for biologist programmers. In S. Krawetz \& S. Misener (Eds.), Bioinformatics Methods and Protocols: Methods in Molecular Biology. (pp. 365-386). Humana Press, Totowa, NJ.

Saitou, N., \& Nei, M. (1987). The neighbor-joining method: A new method for reconstructing phylogenetic trees. MolBiolEvol, 4, 406-425.

Sanderson, M., Thorne, J., Wikstrom, N., \& Bremer, K. (2004). Molecular evidence on plant divergence times. American Journal of Botany, 91, 1656-1665. http://dx.doi.org/10.3732/ajb.91.10.1656

Schomburg, D., \& Salzmann, M. (1990). Class 4: lyases, phenylalanine ammonia-lyase. In D. Schomburg \& M. Salzmann (Ed.), Enzyme Handbook (pp. 1-5) Berlin, Germany: Springer-Verlag.

Schuster, B., \& Rétey, J. (1994). Serine-202 is the putative precursor of the active site dehydroalanine of phenylalanine ammonia-lyase. Site-directed mutagenesis studies on the enzyme from parsley Petroselinumcrispum L. FEBS-Lett, 349, 252-254. http://dx.doi.org/10.1016/0014-5793(94)00681-4

Shufflebottom, D., Edwards, K., Schuch, W., \& Bevan, M. (1993). Transcription of two members of a gene family encoding phenylalanine ammonia-lyase leads to remarkably different cell specificities and induction patterns. The Plant Journal, 3, 835-845. http://dx.doi.org/10.1111/j.1365-313X.1993.00835.x

Sreelakshmi, Y., \& Sharma, R. (2008). Differential regulation of phenylalanine ammonia lyase activity and protein level by light in tomato seedlings. Plant Physiology and Biochemistry, 46, 444-451. http://dx.doi.org/10.1016/j.plaphy.2008.02.001

Stover, R. H. (1980). Sigatoka leaf spot diseases of banana and plantain. Plant Disease, 64, 750-755. http://dx.doi.org/10.1094/PD-64-750

Torres, J., Calderon, H., Rodriguez-Arango, E., Morales, J., \& Arango, R. (2012). Differential induction of pathogenesis-related proteins in banana in response to Mycosphaerella fijiensis infection. European Journal of Plant Pathology, 133, 887-898. http://dx.doi.org/10.1007/s10658-102-0012-7

Wang, Y., Chen, J. Y., Jiang, Y. M., \& Lu, W. J. (2007). Cloning and expression analysis of phenylalanine ammonia-lyase in relation to chilling tolerance in harvested banana fruit. Postharvest Biology and Technology, 44, 34-41. http://dx.doi.org/10.1016/j.postharvbio.2006.11.003 